lent of that observed in culture, and consequently macrophages may be centrally involved in amyloid production. If that is correct, cells of the reticuloendothelial system may become targets for treatment in patients with myeloma.

Support was provided by the University of Cape Town Leukaemia Centre and Staff Research (Cancer) Fund, the National Cancer Institute, the Medical Research Council, the Michael Chanani and Kaliski Bequests and the Gwendoline Moore Trust.
1 Durie BGM, Persky BP, Soehnlen BJ, Grogan TM, Salmon $\mathrm{SE}$, Amyloid production in human myeloma stem-cell culture, with morphologic evidence of amyloid secretion by associated macrophages. $N \mathrm{Engl} f \mathrm{Med} 1982$; 307:1689-92.

2 Glenner GG, Page DL. Amyloid, amyloidosis and amyloidogenesis. Int Rev Exp Pathol 1976;15:1-92.

3 Kyle RA, Bayrd ED. "Primary" systemic amyloidosis and myle RA, Bayrd ED. "Primary" systemic amyloidosis and
myeloma. Discussion of relationship and review of 81 myeloma. Discussion of relationship and

4 Kjeldsberg CR, Eyre HJ, Totzke H. Evidence for intracellular amyloid formation in myeloma. Blood 1977;50:492-504

5 Hopper KE, Wood PR, Nelson DS. Macrophage heterogeneity. Vox Sang 1979;36:257-74.

6 Zucker-Franklin D, Frangione B. Amyloid in myeloma stem-cell culture. $N$ Engl $₹$ Med 1983;308:1164-5.

\title{
Progressive multifocal leucoencephalopathy, sclerosing cholangitis, bronchiectasis and disseminated warts in a patient with primary combined immune deficiency
}

\author{
S A Misbah, G P Spickett, A Zeman, M M Esiri, T B Wallington, J B Kurtz, \\ H M Chapel
}

\begin{abstract}
A 24 year old man presented with an unusual primary combined immune deficiency syndrome characterised by a profound lymphopenia of CD4 cells, selective serum IgG2 subclass deficiency, poor polysaccharide antibody responses, disseminated warts, recurrent sinopulmonary infection and bronchiectasis. The developed progressive multifocal leucoencephalopathy (PML) in association with sclerosing cholangitis.
\end{abstract}

Progressive multifocal leucoencephalopathy (PML) usually occurs as an opportunistic infection in patients with secondary defects in cellular immunity.

Department o

S A Misbah

G P Spickett

H M Chapel

Department of

Neurology

A Zeman

Department of

Neuropathology

M M Esiri

Department of

Virology

J B Kurtz

John Radcliffe

Hospital and Radcliffe

Infirmary, Oxford

Department of

Immunology,

Southwestern Blood

Transfusion Service,

Bristol

T B Wallington

Correspondence to:

Dr S Misbah, Departmen

of Immunology, Level 7

John Radcliffe Hospital,

Oxford OX3 9DU

Accepted for publication

19 November 1991
A caucasian boy born to unrelated parents in 1966 was first seen at another hospital at the age of 3 years on account of flexural eczema, recurrent tonsillitis, and otitis media. By the age of 5 a hoarse voice led to the detection and removal of vocal cord polyps. Two years later generalised warts were first noted. In 1976 a right middle and lower lobe lobectomy was performed for bronchiectasis. Cystic fibrosis was excluded on the basis of a normal sweat test.

In December 1983 a dermatological opinion was sought for extensive warts which covered his neck, trunk, arms and knees. He was noted to be lymphopenic with a low $\mathrm{T}$ helper cell (CD4) count. Human papillomavirus type 3 was detected in a shave biopsy specimen of a wart by DNA hybridisation. He was given etretinate $20 \mathrm{mg}$ daily for one year during which time there was some improvement that was not sustained. HIV serology was negative. In December 1984 Isoprinosine, a $\mathrm{T}$ cell stimulant was given ( $1 \mathrm{~g}$ four times a day) with no objective improvement in his warts. Isoprinosine was discontinued in July 1985. The lymphopenia of CD4 positive cells remained unchanged (fig 1). He was lost to follow up over the next five years until June 1990 when he was transferred to the neurology department at Oxford with a three month history of difficulty in walking, focal seizures, and jaundice of four weeks' duration.

On examination he was cachectic, dyspnoeic, and jaundiced. Disseminated warts and bilateral digital clubbing were noted. Neurologically he was partly orientated, followed simple commands, and could perform basic arithmetic. Bilateral optic atrophy, hypertonic limbs with ankle clonus, hyperreflexia, a right extensor plantar response and bilateral cerebellar deficits were noted. A cranial computed tomogram showed a left cerebellar hemispheric cyst with numerous low density lesions in both thalamic nuclei, right caudate 
Figure 1 Serial lymphocyte counts.

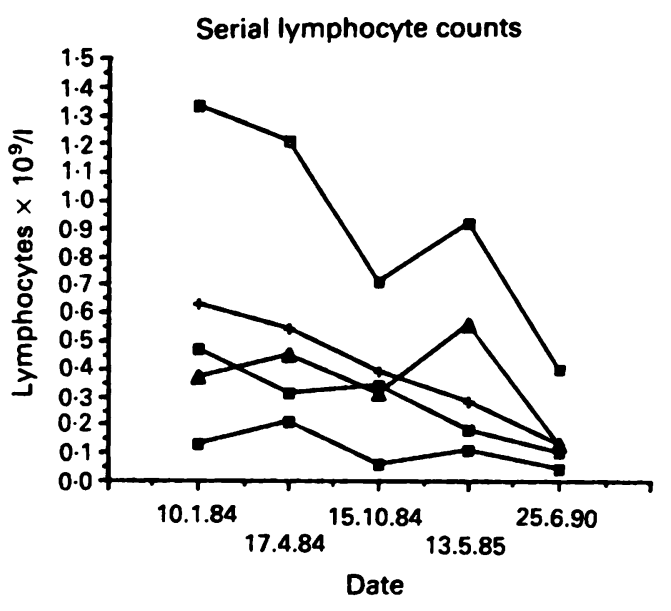

nucleus, and the right parietal lobe. A magnetic resonance imaging scan demonstrated high signal areas in both cerebral hemispheres, the basal ganglia and the left cerebellar hemisphere. Cell markers in peripheral blood are shown in fig 1. Delayed type hypersensitivity skin tests were precluded by the presence of extensive warts.

Table 1 Immunology

\begin{tabular}{|c|c|c|c|c|c|}
\hline Serum & 1972 & 1977 & 1984 & May 1990 & 25.6 .90 \\
\hline $\begin{array}{l}\text { IgG (normal range } 6-13 \mathrm{~g} / \mathrm{l} \text { ) } \\
\text { IgG1 (normal range } 3 \cdot 2-10 \cdot 29 \mathrm{~g} / \mathrm{l} \text { ) } \\
\text { IgG2 (normal range } 1 \cdot 2-6 \cdot 6 \mathrm{~g} / \mathrm{l} \text { ) } \\
\text { IgG3 (normal range } 0 \cdot 2-1 \cdot 9 \mathrm{~g} / \text { ) } \\
\text { IgG4 (normal range } 0 \cdot 0-1 \cdot 3 \mathrm{~g} / \mathrm{l} \text { ) } \\
\text { IgA (normal range } 0 \cdot 8-2 \cdot 5 \mathrm{~g} / \mathrm{l} \text { ) } \\
\text { IgM (normal range } 0 \cdot 4-2 \cdot 5 \mathrm{gl} \text { ) } \\
\text { IgE (normal range }<125 \mathrm{U} / \mathrm{l} \text { ) } \\
\mathrm{C} 3 \text { (normal range } 65-180 \mathrm{mg} / \mathrm{dl} \text { ) } \\
\text { C4 (normal range } 15-50 \mathrm{mg} / \mathrm{dl} \text { ) } \\
\text { Functional antibodies: }\end{array}$ & $\begin{array}{l}8.9 \\
0.5 \\
\text { ND } \\
\text { ND } \\
\text { ND }\end{array}$ & $\begin{array}{l}6 \cdot 1 \\
0 \cdot 38 \\
\text { ND } \\
\text { ND } \\
\text { ND }\end{array}$ & $\begin{array}{l}4 \cdot 0 \\
0 \cdot 14 \\
\text { ND } \\
\text { ND } \\
\text { ND }\end{array}$ & $\begin{array}{r}3.9 \\
0.5 \\
\text { ND } \\
\text { ND } \\
\text { ND }\end{array}$ & $\begin{array}{l}10 \cdot 4 \\
8 \cdot 0 \\
0 \cdot 64 \\
0 \cdot 50 \\
0 \cdot 54 \\
2 \cdot 8 \\
0 \cdot 51 \\
790 \\
158 \\
25 \cdot 2\end{array}$ \\
\hline $\begin{array}{l}\text { Tetanus } \\
\text { Diphtheria } \\
\text { E coli } \\
\text { Pneumococcal polysaccharide } \\
\text { Measles } \\
\text { Varicella zoster } \\
\text { Cytomegalovirus } \\
\text { Hepatitis B surface antigen } \\
\text { Antibodies to HIV } \\
\text { Syphilis serology }\end{array}$ & $\begin{array}{l}\text { ND } \\
\text { ND } \\
\text { ND } \\
\text { ND } \\
\text { ND } \\
\text { ND } \\
\text { ND }\end{array}$ & $\begin{array}{l}\text { ND } \\
\text { ND } \\
\text { ND } \\
\text { ND } \\
\text { ND } \\
\text { ND } \\
\text { ND }\end{array}$ & $\begin{array}{l}\text { ND } \\
\text { ND } \\
\text { ND } \\
\text { ND } \\
\text { ND } \\
\text { ND } \\
\text { ND } \\
\text { Neg }\end{array}$ & $\begin{array}{l}\text { ND } \\
\text { ND } \\
\text { ND } \\
\text { ND } \\
\text { ND } \\
\text { ND } \\
\text { ND } \\
\text { Neg } \\
\text { Neg }\end{array}$ & $\begin{array}{l}1 / 10 \text { (low) } \\
1 / 32 \\
1 / 512 \\
<1 / 16 \text { (low) } \\
<1 / 8 \\
1 / 16 \\
<1 / 8 \\
\text { Neg } \\
\text { Neg } \\
\text { Neg }\end{array}$ \\
\hline $\begin{array}{l}\text { Cerebrospinal fluid } \\
\text { Total protein } \\
\text { Lymphocytes } \\
\text { Other cells } \\
\text { Ziehl-Neelsen stain } \\
\text { India ink stain } \\
\text { Culture for acid fast bacilli }\end{array}$ & \multicolumn{5}{|l|}{$\begin{array}{l}0 \cdot 67 \mathrm{~g} / \mathrm{l}(\mathrm{r} \\
4 \\
\text { Nil } \\
\text { Negative } \\
\text { Negative } \\
\text { Negative }\end{array}$} \\
\hline $\begin{array}{l}\text { Polyoma virus serology } \\
\text { JC } \\
\text { BK } \\
\text { Albumin (mg/dl) } \\
\text { IgG (mg/dl) }\end{array}$ & $\begin{array}{l}\text { Serum } \\
1: 320 \\
1: 1280 \\
3400 \\
890\end{array}$ & $\begin{array}{l}C S F \\
1: 10 \\
1: 5 \\
25 \\
7 \cdot 3\end{array}$ & $\begin{array}{l}\text { Ratio } \\
32: 1 \\
256: 1 \\
136: 1 \\
122: 1\end{array}$ & & \\
\hline
\end{tabular}

$\mathrm{ND}=$ Not done

Table 2 Red cell purine and pyrimidine studies

\begin{tabular}{lrl}
\hline Nucleotide ( $\mu$ molll) & & Normal range \\
\hline Adenosine triphosphate & 2420 & $(1281 \pm 123)$ \\
Adenosine diphosphate & 178 & $(147 \pm 38)$ \\
Adenosine monophosphate & 16 & $(10 \pm 4)$ \\
Guanosine triphosphate & 92 & $(46 \pm 10)$ \\
Guanosine diphosphate & 17 & $(13 \pm 3)$ \\
Nicotinamide adenine dinucleotide & 104 & $(69 \pm 11)$ \\
Nicotinamide adenine dinucleotide phosphate & 63 & $(47 \pm 8)$ \\
Uridine diphosphate glucose & 69 & $(38 \pm 8)$ \\
Orotidine & 18 & $($ normally undetectable) \\
Enzymes (nmol/mg haemoglobin/h) & & \\
Adenine phosphoribosyl transferase & 38 & $(16-32)$ \\
Hypoxanthine guanine phosphoribosyl tranferase & 143 & $(80-130)$ \\
Adenosine deaminase & 78 & $(40-100)$ \\
Purine nucleoside phosphorylase & 6490 & $(3000-7000)$ \\
\hline
\end{tabular}

There was a family history of optic atrophy affecting his maternal uncles, maternal grandmother, and three of her sisters and one brother. Analysis of his mitochondrial DNA showed a point mutation at a site different to that described by Wallace ${ }^{2}$ in classic Leber's optic neuropathy (Poulton et al, personal communication). Further studies are in progress.

\section{Laboratory investigations}

Results of immunological investigation are shown in table 1 and fig 1 .

The results of chemical analyses are as follows: aspartate transaminase 99 IU/1 (normal range 15-42); alkaline phophatase 3379 IU/1 (normal range 80-250); $\gamma$ GT 357 IU/1 (normal range 15-40); bilirubin $194 \mu \mathrm{mol} / 1$ (normal range 3-17); calcium $2.09 \mathrm{mmol} / \mathrm{l}$ (normal range $2 \cdot 1-2 \cdot 6$ ); phosphate $1.0 \mathrm{mmol} /$ 1 (normal range $0 \cdot 8-1 \cdot 45$ ); sodium $142 \mathrm{mmol} /$ 1 (normal range 135-145); potassium $4 \cdot 3$ $\mathrm{mmol} / 1$ (normal range $3 \cdot 5-5 \cdot 0$ ); urea $4 \cdot 1$ $\mathrm{mmol} / 1$ (normal range $2 \cdot 5-6 \cdot 7$ ); creatinine 90 $\mathrm{mmol} / \mathrm{l}$ (normal range 70-150); uric acid 164 $\mu \mathrm{mol} / 1$ (normal range 200-450); $\beta 2$ microglobulin $2.5 \mathrm{mg} / \mathrm{dl}$ (normal range 0-3.0); caeruloplasmin $50.4 \mathrm{mg} / \mathrm{dl}$ (normal range 16-60).

The combination of a predominant defect in cellular immunity and hypouricaemia raised the question of purine nucleoside phosphorylase (PNP) deficiency. Detailed metabolic studies of the purine and pyrimidine pathways were undertaken in conjunction with Dr Anne Simmonds, Guy's Hospital, London, which excluded PNP deficiency (table 2).

A liver biopsy specimen showed focal portal tract fibrosis with a mixed inflammatory cell infiltrate, in the absence of ductular dilatation, highly suggestive of sclerosing cholangitis.

A diagnostic cerebellar biopsy specimen showed very large, bizarre, multinucleate astrocytes (confirmed by a positive reaction for glial fibrillary acidic protein and negative reactions for leucocyte common antigen and epithelial markers). Immunofluorescence studies performed at the Virus Reference Laboratory, Colindale, showed the presence of polyoma JC virus. DNA hybridisation using probes for human papillomavirus (HPV) 1,2 , $3,4,5$, and 6 were negative. Following the diagnosis of PML active treatment was considered inappropriate and he gradually deteriorated and died a few days later.

A limited post mortem examination confined to the head showed a swollen brain (1505 g; forebrain $1328 \mathrm{~g}$ ) with some autolysis and obvious softening of the left cerebellar hemisphere. The large vessels looked healthy while the leptomeninges were diffusely thickened. Acute haemorrhage was noted in the softened white matter of the right parietal lobe.

Histologically in all areas of the cerebrum there were multiple small and moderate sized lesions containing numerous enlarged oligodendrocyte nuclei with basophilic inclusion bodies typical of PML. Some lesions contained 


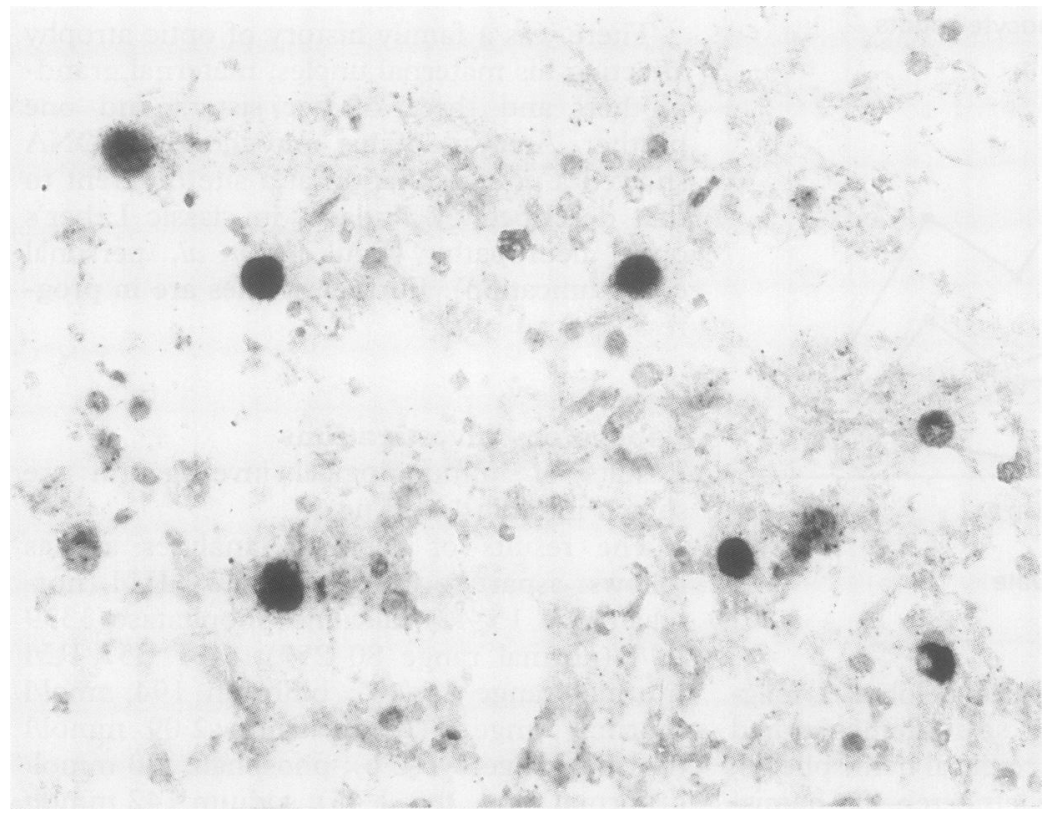

Figure 2 Cerebellar biopsy specimen hybridised with biotinylated $7 C$ virus specific nucleic acid probe. Dark nuclei of oligodendrocytes are those that contain virus (weak haematoxylin counterstain). virus infection, and recurrent sino-pulmonary infection on a background of pronounced $\mathrm{T}$ cell lymphopenia, diminished lymphocyte proliferation to mitogens, decreased interleukin-2 production by mitogen stimulated lymphocytes and poor polysaccharide antibody responses, despite having normal total immunoglobulin concentrations. ${ }^{4}$ Our patient's immune defect approximates closely to that described by Brooks. It would be interesting to see whether any of his patients go on to develop PML in the long term.

The recent description of primary combined immunodeficiency disorders due to defective expression of the $\mathrm{T}$ cell receptor complex ( $\mathrm{Ti}$ CD3) or impaired signal transduction in the presence of a normal Ti-CD3 complex has led to renewed interest in primary deficiencies of cellular immunity. ${ }^{5}$ Patients with the severe form of $T$ cell receptor immunodeficiency present as severe combined immunodeficiency (SCID), but patients with the mild form may remain asymptomatic or manifest a moderate combined immunodeficiency. ${ }^{5}$

Although our patient's lymphocytes expressed normal amounts of CD3 on their cell surface, the possibility of defective signal transduction cannot be ruled out because $T$ cell functional studies were not carried out. To characterise these patients more completely it would be important to quantitate expression of the Ti-CD3 complex in addition to carrying out functional studies-delayed type hypersensitivity skin tests, lymphocyte transformation.

Despite clear evidence of impaired humoral immunity (low IgG2, poor polysaccharide antibody responses, bronchiectasis) in our patient it was felt that immunoglobulin replacement at this late stage would have been unlikely to influence the outcome. The benefits of immunoglobulin replacement in improving lung function have been proved in other antibody deficient patients. In contrast, immunoglobulin replacement is unlikely to have prevented or changed the clinical course of PML.

Serological surveys suggest that exposure to JC virus, the causative agent of PML, is fairly widespread. Although primary infection with the virus is not associated with an identifiable clinical syndrome, the virus may remain latent in the kidneys of some normal subjects until the onset of immunosuppression triggers reactivation. Mori et al have recently reported the detection of JC virus DNA in the brains of apparently immunocompetent elderly patients in the absence of PML, raising the possibility of viral latency in the brain as well. ${ }^{6}$ Since its initial description in $1958 \mathrm{PML}$ has proved to be remarkably resistant to treatment in most patients. A recent report which documents partial therapeutic success with the use of prolonged cytarabine treatment in HIV positive patients with PML is therefore encouraging. $^{7}$

Glioma formation in immunosuppressed subjects with JC virus infection has been described. ${ }^{8}$ Although the bizarre, large, multinucleated astrocytes which were present in the documented. Brooks et al have recently described a kindred with an $\mathrm{X}$-linked combined immunodeficiency where five living males manifested severe varicella, chronic papilloma- 
biopsy specimens from our patient closely resemble those described in the case reported by Castaigne et al, we are not convinced that these cells were part of a truly neoplastic lesion in our case. There was a cyst present in one affected cerebellar hemisphere but no obvious tumour mass was detectable at surgery or necropsy. We therefore regard the bizarre astrocytes, a few of which clearly contained JC virus nucleic acid, as falling at the extreme end of the well recognised spectrum of pleomorphic astrocytic change seen in PML.

The cause of our patient's sclerosing cholangitis was unclear. Sclerosing and ascending bacterial cholangitis have been associated with campylobacter and cryptosporidial infection in patients with primary immune deficiencies. ${ }^{9}$ It has been suggestd that bacterial overgrowth in the upper small intestine may be an important predisposing factor in these cases. Interestingly, primary sclerosing cholangitis in immunocompetent subjects has recently been associated with significantly increased titres of serum antibodies to JC and or BK viruses. ${ }^{10}$ This raises the possibility that reactivation of polyoma virus may have been responsible for both PML and sclerosing cholangitis in our patient.

We thank Professor John Newsome-Davis FRS for permission to report this case. Drs Anne Simmonds and Paul Holloway kindly carried out the biochemical investigations. We thank Lynda Beckley for typing the manuscript.

1 Knight A, O'Brien P, Osoba D. "Spontaneous" progressive multifocal leucoencephalopathy-Immunological aspects. Ann Int Med 1972;77:229-33.

2 Wallace DC, Singh G, Lott MT, et al. Mitochondrial DNA mutation associated with Leber's hereditary optic neuropathy. Science 1988;242:1427-30.

3 Zegers BJM, Stoop JW. Metabolic causes of immunodeficiency mechanisms and treatment. In: Webster ADB, ed. Immunodeficiency and disease. Lancaster: MTP Press, Immunodeficiency

4 Brooks EG, Schmalstieg FC, Wirt DP, et al. A novel $\mathrm{X}$-linked combined immunodeficiency disease. $\mathcal{f}$ Clin Invest 1990;86:1623-31.

5 Alarcon B, Terhost C, Arnaiz-Villena A, et al. Congenital T cell receptor immunodeficiencies in man. Immun Rev 1990;2:1-16.

6 Mori M, Kurate H, Tajuina M, et al. JC virus detection by in-situ hybridization in brain tissue from elderly patients. Ann Neurol 1991;29:428-32.

7 Portegies P, Algra PR, Hollak CEM, et al. Response to cytarabine in progressive multifocal leucoencephalopathy in AIDS. Lancet 1991;337:680-1.

8 Castaigne P, Rondot P, Escourolle R, et al. Leucoencephalopathie multifocale progressive et "gliomes" multiples. Rev pathie multifocale progressive et

9 Webster ADB. Immunodeficiency and the gut. Clin Gastroenterol 1987;1:547-65.

10 Snook JD. Autoimmunity in the pathogenesis of ulcerative colitis. Thesis. University of Oxford, 1991:119-26.

\title{
Isolation of Legionella pneumophila serogroup 14 from a human source
}

\author{
M Castellani Pastoris, C Berchicci, G Pallonari
}

Bacteriology and

Medical Mycology, Istituto Superiore di Sanità 00161 Rome, Italy M Castellani Pastoris C Berchicci

Laboratory of Microbiology, Ospedale S Camillo, Rome, Italy G Pallonari

Correspondence to: Dr M Castellani Pastoris Accepted for publication 1 November 1991

\begin{abstract}
A strain of Legionella pneumophila serogroup 14 was isolated during a retrospective study, after death from the sputum of a patient who had had acute leukaemia and pneumonia. This is the third strain of that serogroup to be isolated from a human source. This event emphasises the importance of performing culture as well as serological tests, so as to detect cases of legionellosis caused by strains which rarely cause fatal clinical illness.
\end{abstract}

Since 1976, when a "new" micro-organism, Legionella pneumophila, was first isolated, ${ }^{1} 14$ serogroups of this species have been described. $^{24-7}$ All serogroups are potential pathogens for humans, but some seem to cause illness more frequently than others.

To our knowledge, only two human isolates of $L$ pneumophila serogroup 14 have been described $^{2}$ : one was isolated at the Minnesota Department of Health, Minneapolis, USA (strain 1169-MN-H); and the other was iso- lated at Ruchill Hospital, Glasgow, Scotland (strain 1586-SCT-H).

\section{Case report}

A 28 year old man in relapse of acute leukaemia after autologous bone marrow transplantation a year previously was admitted to hospital with a 10 day history of fever, followed by diarrhoea, epigastric pain, earache, and a white cell count of $7 \times 10^{8} / 1$. A chest $x$-ray picture was unhelpful. Laboratory examinations showed antibodies to hepatitis viruses $\mathrm{A}$ and $\mathrm{B}$. The patient was initially treated with imipenem, and thereafter with teicoplanin and ceftazidime. After a positive blood culture for Candida pseudotropicalis vancomycin and amphotericin were added. He developed a scantily productive cough. Ceftazidime was replaced with piperacillin. A chest $x$-ray picture four days later showed the presence of confluent densities in the middle right and lower lobes and the left parahilar area. Antibiotic treatment was changed to imipenem and cotrimoxazole. Dyspnoea and peripheral cyanosis appeared the following day, and the 
Lesley Fallowfield serves as a timely reminder which should be essential reading for clinicians. Algorithms are discussed, but we would question their usefulness. The way to learn to diagnose malignant melanomas is to see them and to be taught about them in a clinical setting.

E HIGGINS A DU VIVIER

Systemic Pathology. 3rd ed. Vol 7. Thymus, Lymph Nodes, Spleen and Lymphatics. Ed K Henry, W St C Symmers. (Pp 1042; £140.) Churchill Livingstone. 1992. ISBN 0-443-03429-X

The new Symmers volume on haematopathology is a brave attempt to encompass all you need to know about the subject in a little short of 1000 pages. The stage is set with a short introductory essay on basic immunology and this is followed by what is essentially a comprehensive textbook on the thymus. Three chapters are devoted to the normal lymph node and non-neoplastic lymphadenopathies and are followed by a chapter on the spleen which, curiously, hardly addresses lymphoma. The following chapter of some 350 pages, while entitled "neoplastic disorders of lymphoreticular tissue," deals essentially with lymph node neoplasms with only the occasional mention of extranodal lymphomas. A section on immunohistochemistry rounds off the haematopathology, but is followed by a quite irrelevant chapter on lymphatics which surely belongs elsewhere.

There is much to be commended in this book. With few exceptions, including the extranodal lymphomas referred to above, its coverage is encylopaedic, it is comprehensively illustrated, and the index is unusually good. It is appropriately easy to use and, consequently, will be a useful bench book. The chapter on the thymus is especially valuable because there is no other comparable text on this subject. It is a pity, however, that the Müller-Hermelink classification of thymomas, although praised, is not used.

However, this book cannot be recommended to those seeking enlightenment about this difficult and sometimes controversial branch of pathology. The two short chapters at the beginning and end of the book, on basic immunology and immunohistochemistry, respectively, comprise the only gestures to "science". Molecular genetics, which has contributed so much to recent advances in our understanding of haematopathology, does not feature at all. It is, surely, inexcusible not to have mentioned immunoglobulin light chain restriction, CD10 positivity, immunoglobulin gene rearrangement and the $t(14 ; 18)$ translocation in the 25 pages and 42 illustrations devoted to follicular lymphoma. Pathologists are now much less exercised about the classification of non-Hodgkin's lymphomas than this book would suggest, having settled for either the working formulation or the updated Kiel classification. Developments in immunophenotyping and molecular genetics are beginning to stimulate new thoughts about lymphoma classification, but in this respect the book moves decisively backwards to the largely abandoned classification of the British National Lymphoma Investigation.

The publishers of this series have, for some reason, chosen to persist with the same dull format as that of the first (1966) edition. The illustrations are also rather flat and grey. The aim seems to be to present British pathology as a dignified, conservative descriptive discipline; this accentuates the faults of this book better.

P G ISAACSON

Biopsy Pathology of the Skin. N Kirkham. Biopsy Pathology Series 16. (Pp 396; £59.50.) Chapman \& Hall. 1991. ISBN 0 412350807

I must admit to being a little sceptical when this compact volume of just under 400 pages arrived on my desk. This scepticism arose from my doubt that a book purporting to cover biopsy pathology of the skin could be easily carried in my overcoat pocket.

I had a pleasant surprise. Not only did I find this book easy to read (probably due to Dr Kirkham's rather anecdotal and idiosyncratic style) but also when put to the acid test of lying next to my microscope for a few weeks I found myself referring to it rather more often than some of the larger texts on my shelf. Obviously a book of this size cannot and does not claim to be comprehensive. I think that the balance of the various sections is about right and some of the more contentious areas of dermatopathology, such as the melanocytic lesions, are given ample consideration. Any shortfalls in the included material are to some extent compensated by the remarkably up to date references. The photomicrographs, both colour and black and white, are good and the index appears to work pretty well. All in all this book is good value and is yet another worthwhile addition to this series. and masks its strengths. The authors deserve

S HUMPHREYS

NOTICES

ACP Locum Bureau
The Association of Clinical Pathologists
runs a locum bureau for consultant path-
ologists.
Applicants with the MRCPath who
would like to do locums and anyone
requiring a locum should contact The
General Secretary, 221 Preston Road,
Brighton BN1 6SA. Tel (0273) 561188.
Fax: (0273) 541227.

\section{Melanoma '93}

A joint meeting of the Royal College of Pathologists and the Melanoma Study Group, sponsored by the South East Thames Regional Health Authority Quality Initiative.

6 and 7 May 1993,

\section{Brighton Conference Centre}

This two day consensus conference will address problems in the biopsy diagnosis of melanocytic disorders. As well as formal presentations by Bernard Ackerman (New York) and David Elder (Philadelphia), the programme will include presentations and discussions of proffered cases and papers. Hotel accommodation and car parking will be available at discount rates. The conference takes place during the Brighton International Festival. A spouse programme will be available.

Further details are available from $\operatorname{Dr} \mathrm{N}$ Kirkham, Dept. of Histopathology, Royal Sussex County Hospital, Brighton BN2 5BE, UK. Fax: 0273-600182.

\section{Corrections}

An author's name was accidentally omitted from the list on a piece of correspondence: Current views on cervical neoplasia ( $\mathcal{F}$ Clin Pathol 1992;45:643). We apologise to Dr R A Burnett.

In the same issue the legend of the following figure was incomplete (Misbah et al, $\mathcal{f}$ Clin Pathol 1992;45:624-7). The correct version is reproduced below:

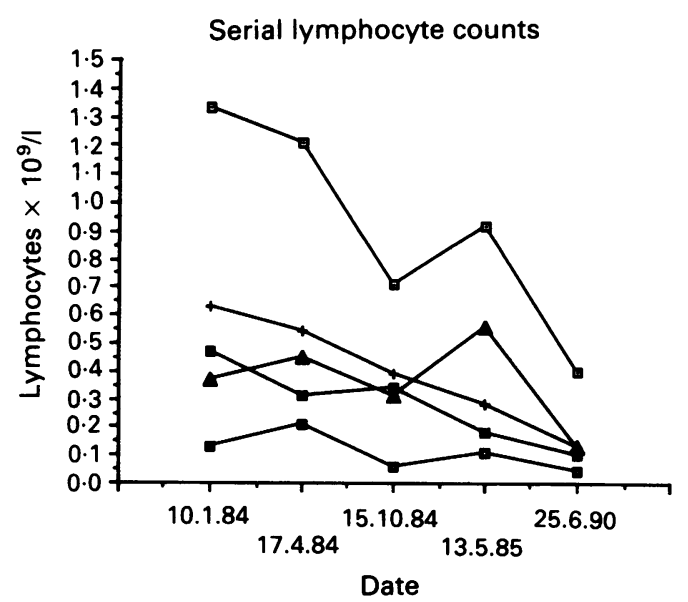

Figure 1 Serial lymphocyte counts. Normal ranges: - - total lymphocytes $(2 \cdot 0-4 \cdot 0) \times 10^{9} / l$,

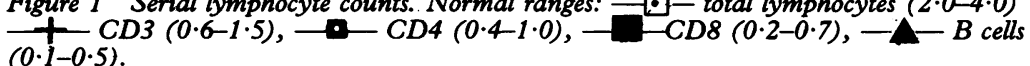

